\title{
Assessment of the Acoustic Performance of Historical Structures That Shed Light on Today's Technologies: Fatih Pasha (Kurşunlu) Mosque - Diyarbakır
}

\author{
Derya Çakır Aydın ${ }^{1, *}$, Filiz Bal Koçyiğit' ${ }^{2}$, Neslihan Dalkılıç³ \\ ${ }^{1}$ Dicle University, Faculty of Architecture, Department of Architecture, Diyarbakır, Turkey, 0000-0002-1376-8444 \\ dcaydin@dicle.edu.tr \\ ${ }^{2}$ Attlım University, Faculty of Fine Arts Design \& Architecture, Department of Architecture, Ankara, Turkey, 0000-0003-4191-0724, \\ filiz.kocyigit@atilim.edu.tr
}

${ }^{3}$ Dicle University, Faculty of Architecture, Department of Architecture, Diyarbakır, Turkey, 0000-0003-3920-9904, neslidal@ dicle.edu.tr

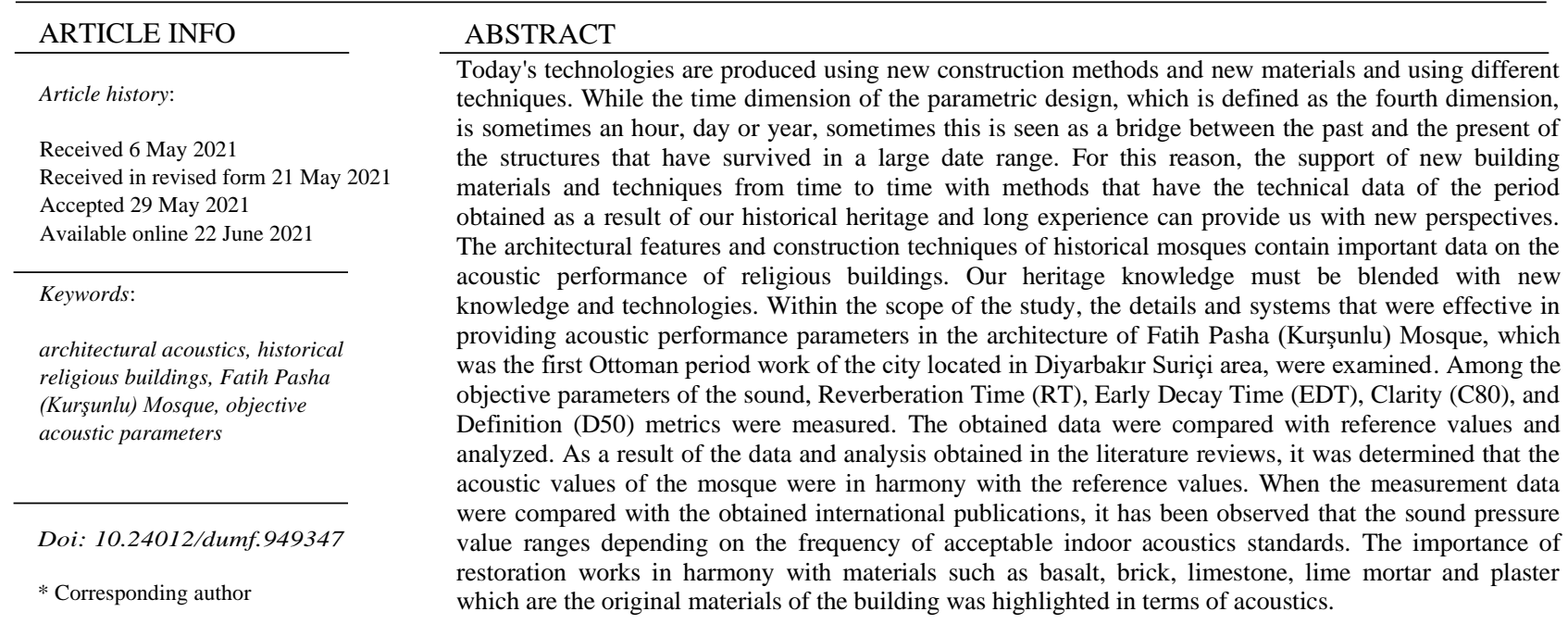

\section{Introduction}

Historical buildings can be regarded as an information heritage from the past to the present. While the time dimension of the parametric design, which is defined as the fourth dimension, is sometimes an hour, day or year, sometimes this is seen as a bridge between the past and the present of the structures that have survived in a large date range. For this reason, the support of new building materials and techniques from time to time with methods that have the technical data of the period obtained as a result of our historical heritage and long experience can provide us with new perspectives. The architectural features and construction techniques of historical mosques contain important data on the acoustic performance of religious buildings. Our heritage knowledge must be blended with new knowledge and technologies. Due to these neglected data, only official data were used in restoration stages in studies related to different social structures until recently, knowledge accumulation and the technical details below were ignored. Similarly, the perception of indoor acoustic characteristics on users has been ignored in historical faith centers. However, mosques, which are one of the important places of the Islamic world, should be evaluated in terms of acoustic comfort in order to ensure the comprehension of Qur'an reading, imam commands, and sermons, and to improve the spiritual feeling of the people of the mawlids and hymns performed with human voice without the use of instruments. Due to the lack of known methods that provide acoustic comfort conditions in many buildings until our time, incorrect restoration works were carried out and the techniques that existed during the period were partially damaged. Instead of original materials, materials that would disrupt the acoustic comfort were used, and the mouths of the acoustic pots, which function as resonators, were covered with plaster. 
The primary aim of this study is to draw attention to the acoustic properties of historical buildings and to minimize data loss that would impair acoustic comfort during restoration. In the field study, the acoustic metrics in Fatih Pasha (Kurşunlu) Mosque, which was recently restored and opened to worship, were measured and compared with the reference values given for mosques in the literature [17].

\section{Fatih Pasha (Kurşunlu) Mosque}

Fatih Pasha Mosque, which was evaluated within the scope of the study, was built in 1516-1520 by Governor Biyıklı Mehmet Pasha. It was the first Ottoman period artefact in Diyarbakir. The mosque, popularly known as the Kurşunlu Mosque because of its lead-covered domes, is located in the eastern part of the old city surrounded by walls [8], [9]. The mosque was built as a part of a complex. The complex consists of a mosque, two tombs and a Shafi'i section. In the northwest corner, there is a single honorable minaret adjacent to the structure, a tomb, and in the northeast, there is the Tomb of Özdemiroglu Osman Pasha, which is independent of the structure. There is hazire ${ }^{1}$ in the east and south [8-10] (Fig.1).

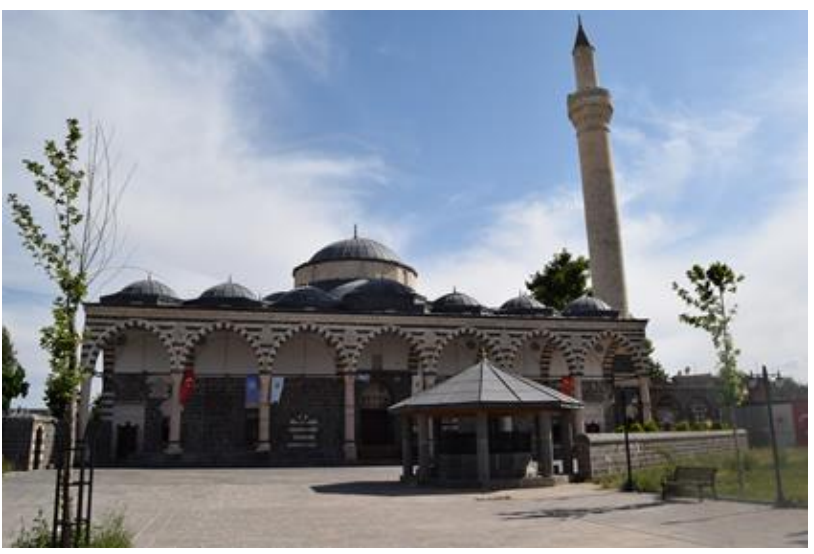

Figure 1. Fatih Pasha Mosque

Kurşunlu Mosque and its hazire were registered and protected by the Diyarbakir Regional Council for the Protection of Cultural and Natural Assets in 1991. Mosque, by the General Directorate of Foundations in 1960, repaired in 1975-1976, 1981-1983, and 2008 [11], it suffered a major fire and damage as a result of the events in Suriçi in December 2015.The mosque, which underwent a comprehensive restoration between 2016 and 2019, was reopened for worship in March 2019.

Fatih Pasha Mosque shows the characteristics of classical Ottoman art with its plan, architectural features and materials [10]. The mosque consisted of a square-planned $(20.24 \times 20 \mathrm{~m}$.) prayer hall and a seven-unit final congregation along the northern façade. It has an area of approximately $420 \mathrm{~m}^{2}$ and a volume of approximately $4520 \mathrm{~m}^{3}$, including the women's mahfil. The prayer hall

\footnotetext{
1 Burial area reserved for special people especially in mosques
}

part of the mosque has a central plan supported by four half domes. The first standout point when entering through the main door is the cover system built on four square feet. A dome in the middle and four half domes in four directions around it reflect the characteristics of a central structure with four small domes in the corners [8]. A hexagonal pulley carries the central dome. Eight pointed arched windows were opened in the pulley. Half domes sit on half octagonal pulleys. Pulleys end with a row of hedgehog fringes as an early feature [10]. In the northeast and northwest corners of the prayer hall and just behind the narthex, there is a square-planned, domed room $(5.2 \times 5 \mathrm{~m})$ (Fig.2)

Basalt was used in the fine part of the last congregation place and in the important parts of the building, and rubble basalt was used in the other parts. In particular, the last congregation place, pulley, and in some parts, smooth cutting basalt were used.

The interior is entered through the arched doorway in the middle of the last congregational place. The dome, which is carried by four square sequins in the middle, has been expanded with half domes in four directions. The spaces in the corners are covered with small domes. Half domes and corner domes are tromp-pass. The most moving part of the structure, whose walls are usually simple, is the mihrab and minbar in the middle of the qibla wall. On the qibla wall, two-storey window arrangement can be seen on both sides of the mihrab. On the east and west walls, the three-storey in the middle and the other at the bottom of the two storeys are seen with flat lento pressed arch foreheads, and at the top with pointed arches, the top with pressed arches are seen.

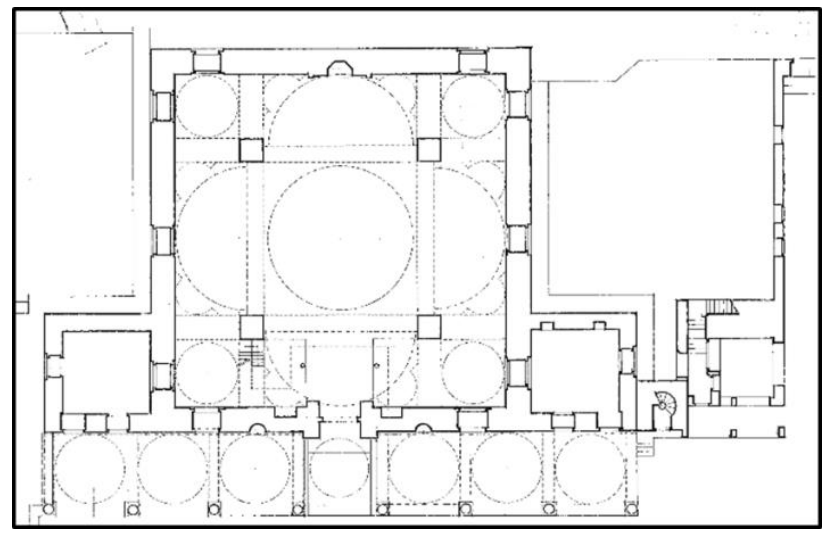

Figure 2. The plan of the Fatih Pasha Mosque [12]

In the north of the mosque, there is a seven-domed last congregation place. In the middle of the last congregational place, there is an iwan-type crown door with pointed arches, which is carried outward. There are colonnades on both sides. There is a rectangular opening window above the door. On the right and left of the crown door, there is a window with flat lento, pointed arch foreheads, and an mihrab made of two-colored stones, a door with a pressed arch, and a two-story window. The 
lower windows have a pointed arch forehead with a straight lento, and those at the top have a pointed arch opening. The last congregational place is covered with five domes. Above the middle section of the mosque entrance, the dome is animated by triangular prism cabinets between the inner trumpets. There are rich examples of chasing in other dome interiors and passages. These chasing have a vegetative character and are not original. It is not known when the original chasing ornaments were removed. Today's pen-made ornaments were originally made in the 2008 repairs. The last congregational place to open out with pointed arches sitting on eight columns has a moving image with twocolored stonework outside the monochrome white columns [10].

During the restoration application carried out between 2016 and 2019, all the plasters of the mosque, which were damaged by fire and renewed in 2008, were removed and replaced with lime plaster compatible with the original. Only the surface where the original chasing in the dome were found was not removed but was reinforced by cleaning. In this process, almost all the plasters on the inner surface were removed, so the original wall and top covering materials and acoustic pots placed in the domes could be seen.

The mihrab of the mosque is made of finely cut limestone. In the past, it is known that the mihrab is covered with tiles. But today there is no sign of tiles. The minbar and door on the right of the mihrab are marble (Fig.3). A wooden dome with geometric decoration was later added to the throne section of the minbar with the cage carving technique. All the wall surfaces of the structure, which are still plastered today, are basalt rubble stones, while the feet and arch stones are made of smooth basalt cut stones. The main construction material of all domes is brick. It is covered with lime plaster. The original flooring material is basalt. It is then covered with carpet. It has been supported to reduce the interior reverberation time by using carpet covering over basalt stone as flooring. Accessed by a basalt staircase, the women's mahfil is made of wooden flooring and wooden railing carried by wooden posts. The flooring is covered with carpet. The main entrance door of the mosque and the profiles of the windows are also wooden.

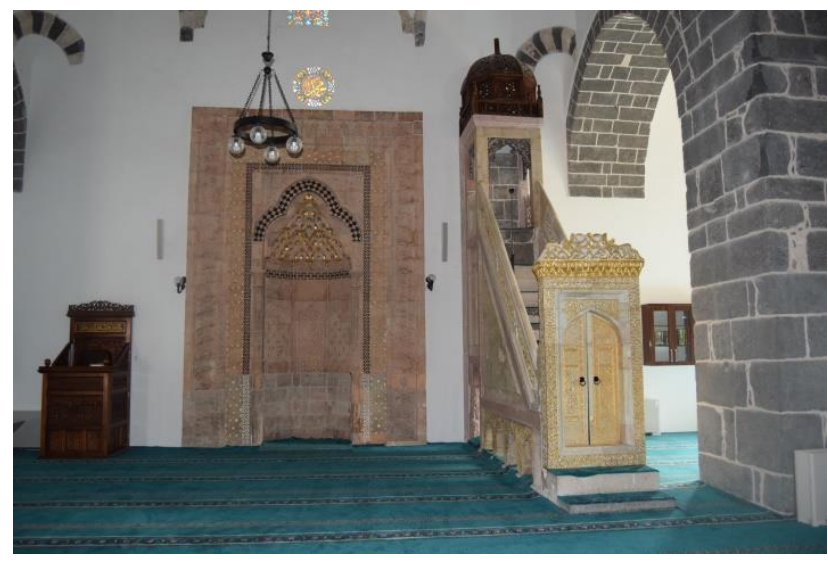

Figure 3. The minbar and the mihrab in the qibla wall
In the original state of the mosque, the building and finishing materials, terracotta materials such as brick and pipe, basalt stone, limestone, marble, mortars, plaster and paint layers, glass, wood and carpet were identified. Most of the surfaces in the prayer hall are covered with stucco and carved decorations.

Pots used as acoustic resonators were uncovered in the mosque with plasters removed after the fire. Resonators have become a kind of practice over time, especially in mosques, which are a religious structure. In the 16th century, Sinan also widely used acoustic resonators in its mosques [13]. The simplest type of acoustic resonator is the Helmholtz resonator. This is a volume of air that is connected to the volume of the room with a small opening and neck as soon as it is located in a cavity of a full mass (Fig.4). The sound energy that strikes causes the air in the neck to vibrate. This air tends to hare as a mass, such as a spring, which also includes the air behind the cavity due to compressed volume. This spring-mass system has a resonance frequency and is the maximum energy transfer when they are at the same frequency as the multiplier sound wave. Energy is swallowed by rubbing against the neck and the air particles inside. Some of the energy is transmitted into the cavity inside and continues to spread again until the sound stops. Therefore, resonators can extend reverberant sound energy in-room volume. If the inner surface of the resonator used is not swallowing, it will come out very quickly at frequencies above and below its own resonance frequency. That is, if the resonator is in the swallower feature, it will be effective in a larger bandwidth. The sound energy emitted back into space will also decrease due to the ingestion of energy [14]. Equation (1) [13] displays the formula that can be used to calculate the resonance frequency of the resonators soon as it is selected. The acoustic pot in the dome of the mosque can be seen in Fig. 5 .

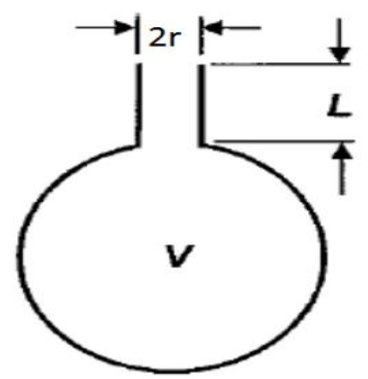

Figure 4. Helmholtz Resonator schematic shape

$$
f=\frac{c r}{2 \pi} \sqrt{\frac{2 \pi}{(2 L+\pi r) V}}
$$

c: The speed of sound in the air

$r$ : Neck redious

L: Neck length

V: Cavity volume 


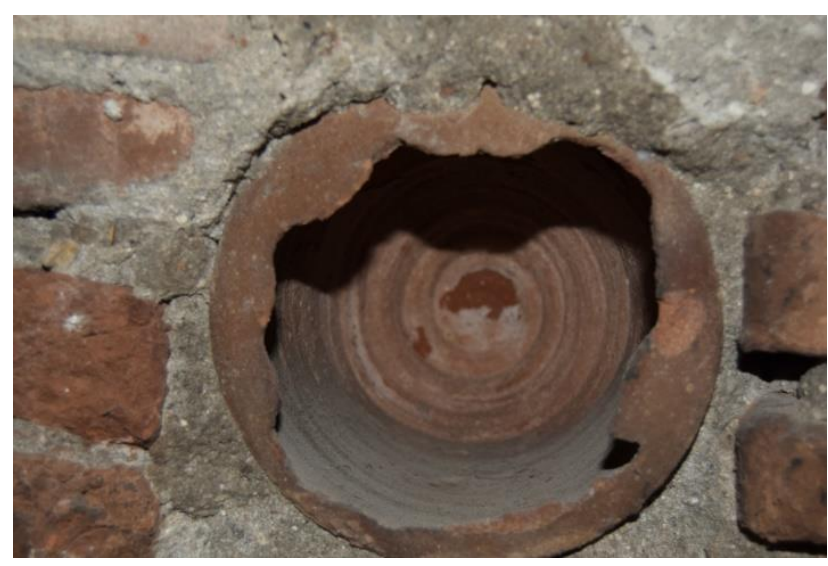

Figure 5. Acoustic pot in the dome

\section{Methodology for Objective Field Measurements}

In the study, fieldwork was carried out to determine the acoustic performance of Fatih Pasha (Kurşunlu) Mosque, a historical mosque. Field measurements in the mosque are in accordance with TS EN ISO 3382-1 standard [1] and the space is empty. B\&K 4292-L (Omnipower sound source) was used as the sound source in the measurements. According to the level of background sound, the volume is regulated with the B\&K 2734 power amplifier. Metrics were measured with B\&K 2270 Sound Level Meter using ODEON-15-Auditorium software. The microphone is controlled with the $\mathrm{B} \& \mathrm{~K} 4231$ sound calibrator before and after measurements. Background noise level, Reverberation Time (RT), Early Decay Time (EDT), Clarity (C80), and Definition (D50) metrics were measured as part of the study.

The background noise level refers to the total sound that other sources in the environment created at the same time when the noise source examined in an environment is silenced [15]. The sounds that make up the background sound can mask the sound source in the space and reduce comprehension. For this reason, it is preferred that the background noise level inside the space and the sound coming from outside at the time of the activities inside the space are not noticeable and does not mask the sound inside the space. The background noise level for mosques should not exceed $34 \mathrm{dBA}$ or noise criterions NC-25 [16].

The most determining parameter affecting the comfort conditions in room acoustics is the reverberation time. The time it takes for a sound pressure level to decrease by 60 $\mathrm{dB}$ from the silence of a sound source is called reverberation time (RT). In the middle and high frequencies, low reverberation times are required to ensure the comprehensibility of sermons, while at lower frequencies, longer reverberation times are required to develop the spiritual feeling in the recitation of mawlids and hymns. The higher the reverberation time, the more vivid the sound field in the room, the lower the dryer and deader. Very long reverberation times will negatively affect speech intelligibility, while very short reverberation times will reduce the sense of adequate feedback and envelopment of the space [17].

According to Su Gul and Caliskan (2013), optimum reverberation time limits for $500 \mathrm{~Hz}-1000 \mathrm{~Hz}$ are indicated in Table 1 [2]. According to Karabiber and Erdoğan (2002), the optimum levels for functions performed in mosques are between 1.7 and 2.8 seconds [3]. Bal Koçyiğit (2014) showed the optimum time for $500 \mathrm{~Hz}$ $1000 \mathrm{~Hz}$ as $1.2 \mathrm{sn}-3.0 \mathrm{sn}$ (Fig. 6) [4].

Early Decay Time (EDT) refers to the time until the sound from the source decreases by $10 \mathrm{~dB}$. EDT is important in terms of subjective perception of reverberation time. In music halls, the EDT value is required to be $10 \%$ higher than the T30 value and in speaking halls, they may have values close to each other [5].

Table 1. Optimum reverberation time for mosques [2]

\begin{tabular}{ccc}
\hline $\begin{array}{c}\text { Acoustic } \\
\text { Parameters }\end{array}$ & $\begin{array}{c}\text { Optimum } \\
\text { Limits }\end{array}$ & $\begin{array}{c}\text { Only } \\
\text { Noticeable } \\
\text { Difference }\end{array}$ \\
\hline $\begin{array}{c}\text { Reverberation Time } \\
(\mathrm{T} 30 \text { average of }\end{array}$ & $1.8 \mathrm{~s}-2.2 \mathrm{~s}$ & $\% 5(0.1 \mathrm{~s})$ \\
$500 \mathrm{~Hz}$ and $1 \mathrm{kHz})$ & & \\
\hline
\end{tabular}

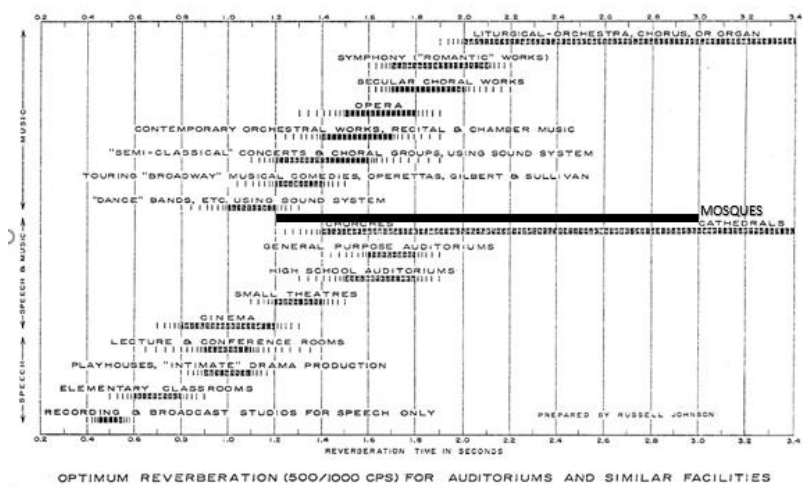

Figure 6. Optimum reverberation time (RT) for different functions [4]

Clarity (C80) is the ratio of the early sound energy coming to the receiver (the direct sound level in the first $80 \mathrm{~ms}$ ) to the late sound energy (the reverberating sound level after $80 \mathrm{~ms}$ ). The early to late energy ratio in $\mathrm{dB}$ using sound energy in the first $80 \mathrm{~ms}$ as the 'early' part. C80 is most often used as an indicator of coro and religious ritual clarity. These limits are -1 and $+3 \mathrm{~dB}$ range for coro and religious ritual [6].

Definition-D50 (\%) is defined as the ratio of the energy of the first reflections reaching the receiving point within the first $50 \mathrm{~ms}$ period to the total sound energy reaching the receiver. Obviously, the 'definition' is a useful descriptor of speech intelligibility. As the D50 increases, the comprehension of speech increases. When the value of the 
D50 rises above 50\%, the comprehension of speech exceeds 90\% [7]. According to TS EN ISO 3382-1, the optimum limit values are between 0.30-0.70 [1].

At the beginning of the work, the background noise level was measured primarily at four points of the mosque (A1, A2, A3, A4). Acoustic parameters were measured at three sound sources and 25 receiver points in order to determine the acoustic performance of the mosque. Three source points (S1, S2, S3) were determined for the measurements. $\mathrm{S} 1$ is positioned in front of the mihrab, $\mathrm{S} 2$ is in the minbar, and S3 is located in the center of the prayer hall. 25 receiver points are designated to be at least $3 \mathrm{~m}$ between them. One of the receiver points is on the women's mahfil and the others on the ground floor (Fig. 7).
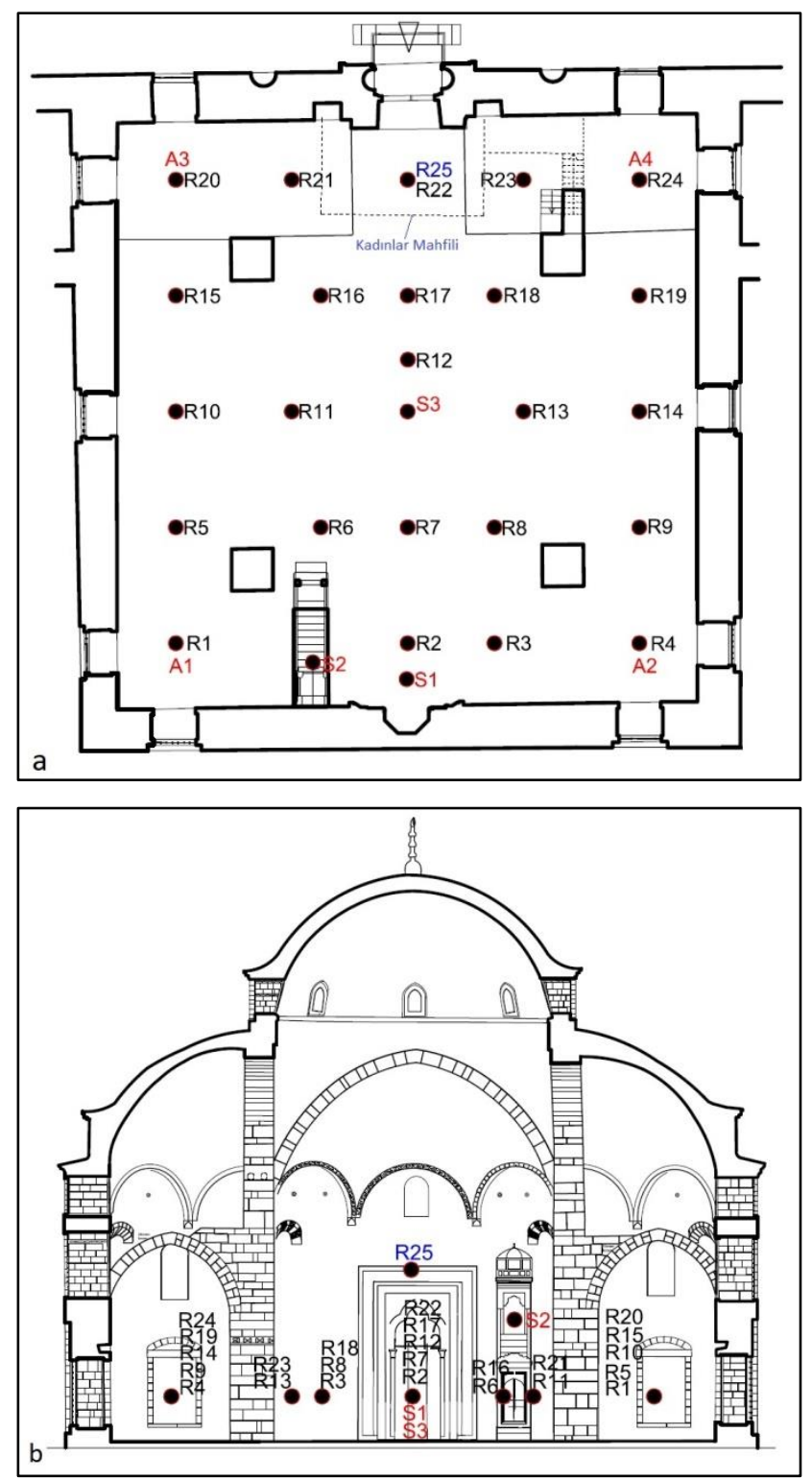

Figure 7. The positions of the Source-Receiver points in a) plan, b) section
The distances between the sources and receivers and their distances from the nearest reflective surface are arranged to be at least $1.5 \mathrm{~m}$. Sound sources are positioned at a height of $1.5 \mathrm{~m}$ from the floor. Since the source $\mathrm{S} 1$ is determined as the position of the imam to pray to the congregation in front of the mihrab, the receiver points are $1.5 \mathrm{~m}$ high from the floor; For the S2 source placed on the minbar, the congregation listened to the Friday sermons by sitting, so receiver points have a height of $0.8 \mathrm{~m}$; For the $\mathrm{S} 3$ source placed in the center, the receivers were placed $0.8 \mathrm{~m}$ above the floor.

\section{Results}

In the measurement study carried out in the prayer hall section of Fatih Pasha (Kurşunlu) Mosque; Background Noise Level, Reverberation Time (RT), Early Decay Time (EDT), Clarity (C80), and Definition (D50) parameters were performed as part of the study. The acoustic performance of the mosque was evaluated by analyzing the obtained data according to reference data.

Construction works are underway around the mosque, which is located in a historical area. Although the noise from construction works outside the building is high, this level decreases within the mosque. When the background noise level of the mosque is evaluated; as stated in Table 2 , it is seen that the background noise level does not increase to $34 \mathrm{dBA}$ limit value at all four points measured within the mosque.

Table 2. Measured background noise levels at four measurement points

\begin{tabular}{|c|c|c|c|}
\hline \multicolumn{4}{|c|}{ Background Noise Levels } \\
\hline A1 & A2 & A3 & A4 \\
\hline 32 dBA & 31,6 dBA & 32 dBA & 29 dBA \\
\hline
\end{tabular}

The Figure 8 and Table 3 show the average RT of 25 receivers with reverberation time between $125-4000 \mathrm{~Hz}$ obtained from R1-R25 for the S1 source placed in front of the mihrab, the S2 source placed on the minbar and the S3 source placed in the center has been given. The average reverberation time of 25 receivers for $500 \mathrm{~Hz}-1000 \mathrm{~Hz}$ at S1, S2, S3 sources ranges from $2.66 \mathrm{sn}-2.69 \mathrm{sn}$ for $500 \mathrm{~Hz}$ to $2.03 \mathrm{sn}-2.04 \mathrm{sn}$ for $1000 \mathrm{~Hz}$. Compared to the optimum value specified by Su Gul and Caliskan (2013) at 1.8sn$2.2 \mathrm{sn}$, it is in $1000 \mathrm{~Hz}$ reference data and above $500 \mathrm{~Hz}$; It is among the reference data according to the optimum level specified by Karabiber and Erdogan (2002) between 1.7 and 2.8 seconds and according to Bal Koçyiğit's range of 1.2-3.00 seconds. 

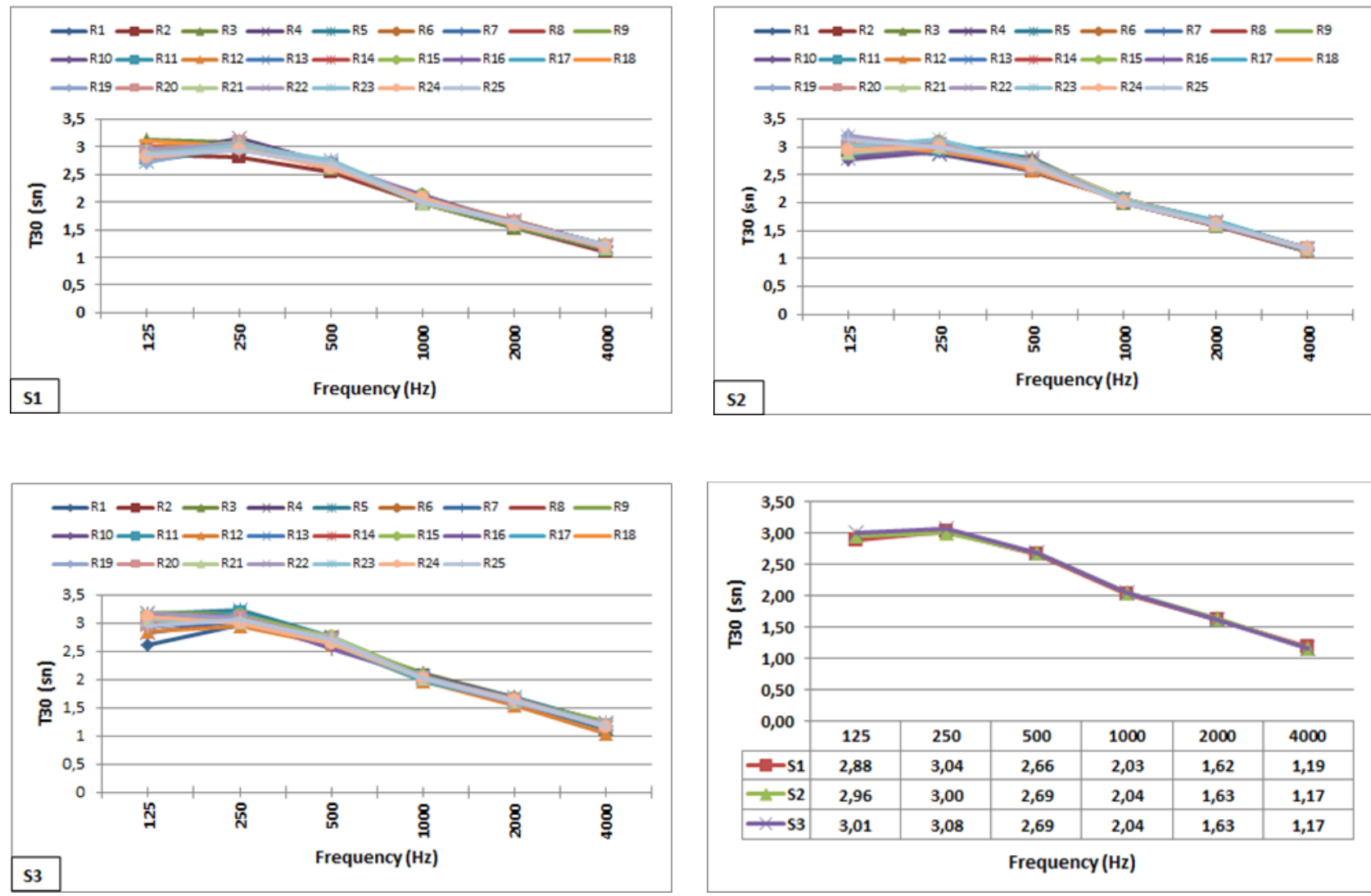

Figure 8. Average RT graphics from 25 receiver points and receivers for S1, S2, S3 sound sources

Table 3. T30 graphics according to placement of 25 receivers

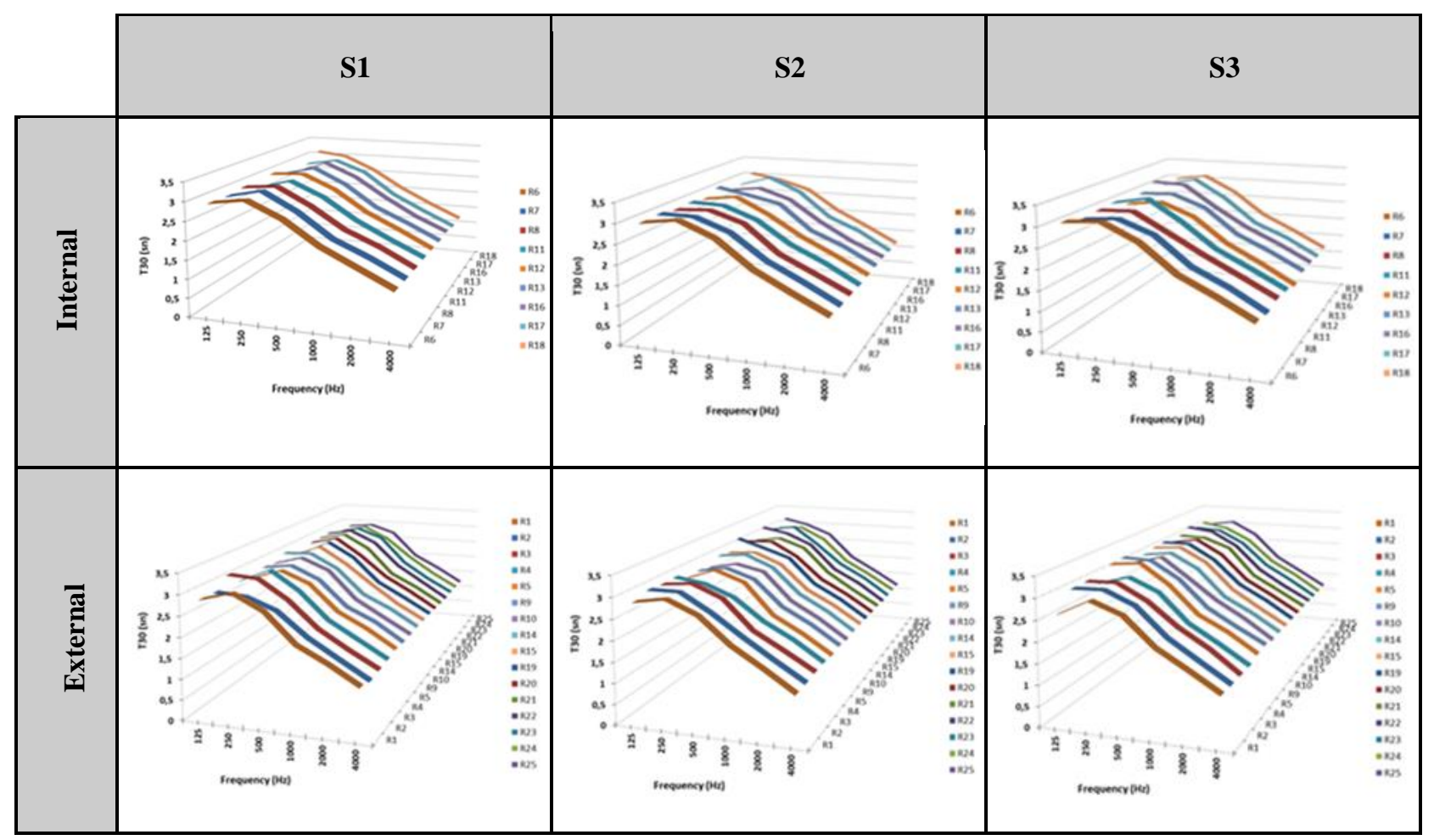


For S1-S2-S3 source points, Fig. 9 shows the average EDT data between $125-4000 \mathrm{~Hz}$ obtained from R1-R25 receiver points is given. The average EDT of 25 receivers for $500 \mathrm{~Hz}-1000 \mathrm{~Hz}$ at $\mathrm{S} 1, \mathrm{~S} 2, \mathrm{~S} 3$ source points ranges from $2.50 \mathrm{sn}-2.64 \mathrm{sn}$ for $500 \mathrm{~Hz}$ to $1.97 \mathrm{sn}-2.06 \mathrm{sn}$ for $1000 \mathrm{~Hz}$. These data were found to be among the reference data because the EDT must be $\pm 10 \%$ of the T30 value.

In Fig.10 shows the average C80 data between 125-4000 $\mathrm{Hz}$ from R1-R25 receiver points for $\mathrm{S} 1-\mathrm{S} 2-\mathrm{S} 3$ source points is also provided. At the $\mathrm{S} 1, \mathrm{~S} 2, \mathrm{~S} 3$ source points, it was determined that the average $\mathrm{C} 80$ of 25 receivers was at reference for $1000 \mathrm{~Hz}$ compared to the reference values -1 and $+3 \mathrm{~dB}$, and slightly below the reference for $500 \mathrm{~Hz}$.

For S1-S2-S3 source points, Figure 11 shows the average D50 data between $125-4000 \mathrm{~Hz}$ obtained from R1-R25 receiving points is also given. According to TS EN ISO $3382-1$, the D50 values of the mosque are below the optimum limit value in S1 and S2 sources for $250 \mathrm{~Hz}$, all other data are among the reference data.

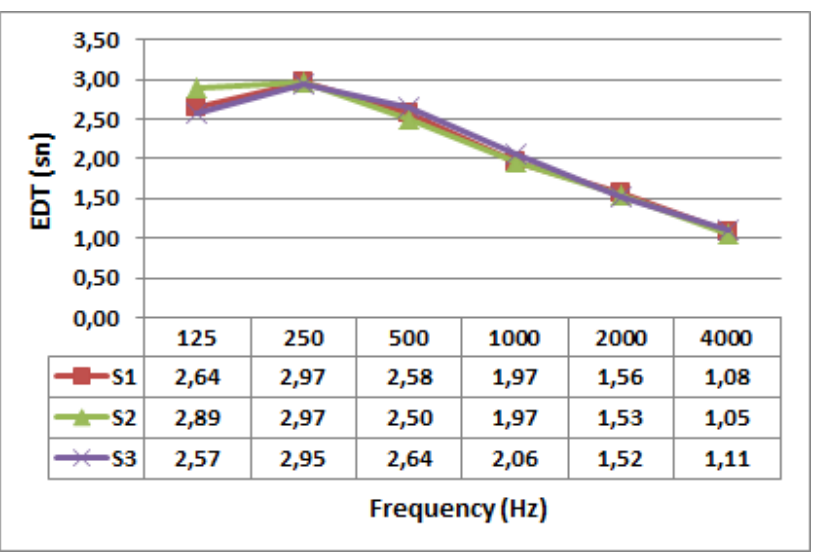

Figure 9. Average EDT for 25 receiver points for S1, S2, $\mathrm{S} 3$ sources

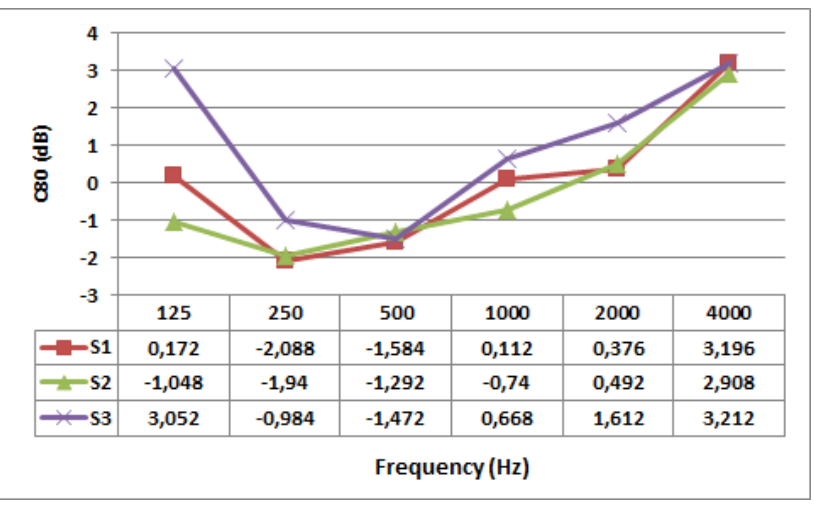

Figure 10. Average C80 for 25 receiver points for S1, S2, $\mathrm{S} 3$ sources

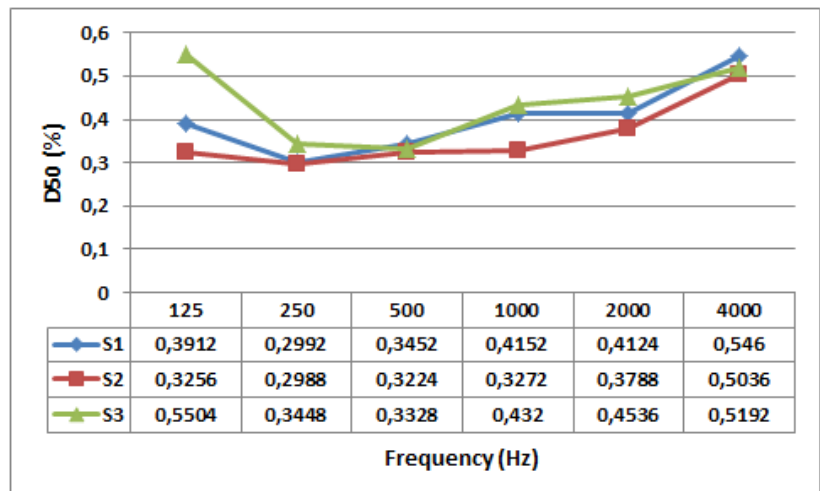

Figure 11. Average D50 for 25 receiver points for S1, S2, S3 sources

\section{Conclusion}

Indoor acoustic comfort in mosques is to ensure that the users in the space hear the sound of the imam and the muezzin at the same quality at every point, and to ensure sound quality in terms of the comprehensibility of talking to each other. Since the music in mosques is usually caused by the human voice and narrowband intermittent sounds used in rehabilitative sounds at medium frequencies, it does not require high reverberation time in indoor acoustic control in mosques. Compared to other religious places, this situation supports the control of the reverberation time since the floor is covered with carpet in mosques.

In the measurements made in the study, T30 values, which are high at low frequencies, were obtained at low levels at medium and high frequencies, due to the high differences in sound absorption coefficient values in octave band frequency ranges on carpeted surfaces. The reverberation time (RT) of the mosque is in the acceptable range, especially at $500 \mathrm{~Hz}$ and $1000 \mathrm{~Hz}$. EDT values are among reference values, reference values for $1000 \mathrm{~Hz}$ in C80 data, and slightly below the reference value for $500 \mathrm{~Hz}$. D50 is below the optimum limit value in S1 and S2 sources for $250 \mathrm{~Hz}$, all other data are among the reference values.

This study has shown that the architectural features and construction techniques of historical mosques contain important data on the acoustic performance of religious buildings. The fact that the restoration applications were made in harmony with the original materials of the building proved that these data, which provide the acoustic comfort conditions, are preserved. For this reason, it is beneficial to transfer our heritage information to contemporary mosque designs by blending it with new knowledge and technologies.

\section{Acknowledgements}

This research was supported by DUBAP (MIMARLIK.19.003), Dicle University, Turkey. 


\section{References}

[1] TS EN ISO 3382-1: Acoustics - Measurement of Room Acoustic Parameters. Part 1: Performance Spaces, 2009.

[2] M. Caliskan and Z. Sü Gül, "Acoustical design of Turkish Religious Affairs Mosque," ICA 2013, 2013, no. 2-7 June.

[3] Z. Karabiber and S. Erdogan, "Comparison of the Acoustical Properties of an Ancient and a Recent Mosque," Forum Acusticum, 2002.

[4] F. Bal Koçyiğit, "Evaluation of acoustic diversity of religious buildings; a case study from churches and mosques in Turkey," 167th Acoustical Society of America Meeting, 2014.

[5] N. N. Çelebi Şeker, "Salonların Mimari Tasarımının Erken Düşme Süresi ve Çınlama Süresi Akustik Parametrelerine Etkisi," Megaron, vol. 16, no. 1, pp. 81-91, 2021.

[6] E. Odabaş, Z. Sü Gül, and M. Çalışkan, "Doğramacızade Ali Pasha Camii'nin Akustik Ölçümlerle Değerlendirilmesi," 9.Ulusal Akustik Kongresi.

[7] H. Kuttruff, Room Acoustics, 5th ed. Abingdon: Oxon:Spon Press, 2009.

[8] M. Sözen, Diyarbakır'da Türk Mimarisi. İstanbul, pp. 65,68,260, 1971.

[9] M. B. Tanman, Fatih Pasha Camii maddesi, 12th ed. İstanbul: Türkiye Diyanet Vakfı İslam Ansiklopedisi, 1995.
[10] İ. Yıldız, "Kurşunlu Camii Kompleksi Sanat Tarihi Raporu," 2016.

[11] Z. Boran, A, Erdal, "Diyarbakır'daki Osmanlı Dönemi Cami ve Mescidleri," Diyarbakır Mimarisi, İ. Yıldız, Ed. Diyarbakır: Diyarbakır Valiliği Kültür ve Sanat Yayınları, 2011, pp. 257264.

[12] Vakıflar Genel Müdürlüğü (VGM) Arşivi, "Vakıflar Genel Müdürlüğü,," Diyarbakır, 1978.

[13] F. Bal Koçyiğit, "Metro İstasyonlarinda Mezanin Katinda Ses Kaynaklarinin Araştirilmasi ve Çözümlenmesi,” Doktora tezi, Gazi Üniversitesi, Fen Bilimleri Enstitüsü, 2003.

[14] A. Lawrence, Architectural Acoustics, no. 1932. Amsterdam-London-New York: Elsevier Publishing Company Limited, 1970.

[15] Çevre ve Şehircilik Bakanlığı, "Çevresel Gürültünün Değerlendirilmesi ve Yönetimi Yönetmeliği," Ankara, 2010.

[16] E. Uysal, "Camilerde Mimari Akustik Tasarım Kriterleri ve Bir Örnek Çalışma: Hasan Tanık Camii," Yüksek Lisans Tezi, Gazi Üniversitesi, Fen Bilimleri Enstitüsü 2015.

[17] Z. S. Gül, M. Çalışkan, and A. Tavukçuoğlu, "Geçmişten Günümüze Süleymaniye Camii Akustiği," Megaron, vol. 9, no. 3, pp. 201-216, 2014. 